\title{
Lecturas sobre el grabado en la Argentina a mediados del siglo XX1
}

\section{Dolinko, Silvia}

Resumen:

El artículo presenta una recorrido en relación con algunas lecturas sobre el rol y significación del grabado que se sostuvieron y circularon en el campo cultural argentino a mediados del siglo $\mathrm{XX}$, considerando los planteos de autores como Gustavo Cochet y Jorge Romero Brest que estaban realizando entonces selecciones y sosteniendo lecturas que con el tiempo devendrían canónicas para la historia del arte.

Palabras clave:

grabado - canon - historiografía - siglo XX - Cochet - Romero Brest.

\section{Cuadernos del Centro de Estudios de} Diseño y Comunicación N ${ }^{\circ} 60$

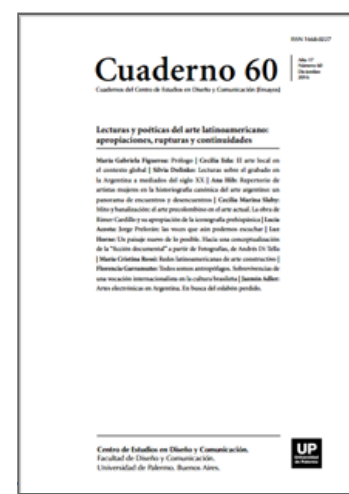

ISSN: 1668-0227

Lecturas y poéticas

del arte

latinoamericano:

apropiaciones,

rupturas y

continuidades

Año XVII, Diciembre 2016, Buenos Aires, Argentina | 176 páginas

$$
\text { descargar PDF ver índice de la publicación }
$$

Ver todos los libros de la publicación

compartir en Facebook

\section{$\left(^{*}\right)$ Doctora en Historia y Teoría del} Arte por la Universidad de Buenos Aires. Investigadora del Conicet. Profesora de Arte argentino y americano del siglo XX en la Maestría en Historia del Arte Argentino y Americano del Instituto de Altos Estudios Sociales de la Universidad Nacional de San Martín (IDAES-UNSAM) y docente de Metodología de la Investigación en la carrera de Artes de la Facultad de Filosofía y Letras de la Universidad de Buenos Aires.

De Durero a Whistler: en 1944, Horacio Caillet-Bois celebraba desde la presentación de un catálogo del Museo Rosa Galisteo de Rodríguez, de la ciudad de Santa Fe, poder "ofrecer a la contemplación del público local un magnífico conjunto de grabados que constituye un panorama bastante completo y representativo de la evolución y la marcha del arte de la incisión a través del tiempo". A la vez, el texto del director del museo señalaba algunas de las problemáticas que se desprendían del complejo posicionamiento del grabado en la consideración del público: La falta de conocimiento de las dificultades intrínsecas del grabado, la poca importancia que, por lo general -e inexplicablemente- se acuerda a esta manifestación artística y la necesidad de una mayor educación estética en el observador común para interpretarla y comprenderla, han hecho que el grabado fuera, en cierto 
sentido, la cenicienta de las artes. Ahora se está reaccionando contra esta despreocupación por parte del público y el grabado adquiere, cada vez más, la jerarquía que auténticamente le corresponde2.

Esta referencia proporciona indicios y un punto de partida para interpretar cuáles fueron las lecturas sobre el rol y significación del grabado que se sostuvieron y circularon en el campo local a mediados del siglo XX. Eran tiempos en que algunos autores como Gustavo Cochet, Julio Payró o Jorge Romero Brest estaban realizando selecciones y sosteniendo lecturas que con el tiempo devendrían canónicas para la historia del arte. ¿Cuál era el espacio asignado al grabado? ¿Qué sentidos, funciones o importancia se le otorgaba? ¿Qué discursos eran los que gravitaban en torno a su definición? I

La Exposición del grabado universal presentada en el Museo Rosa Galisteo en 1944 había sido llevada a Santa Fe por el galerista Federico Müller, quien en ese mismo catálogo reproducía algunos párrafos introductorios sobre la definición del grabado original editados en la versión porteña de la muestra. En los años cuarenta, el Gabinete de Estampas de Müller parecía ser una de las pocas opciones "comerciales" estables para el grabado: eran años en los que las exposiciones de gráfica no formaban parte central de la agenda de las galerías locales. Sin embargo, no deja de resultar un dato relevante que lo que generalmente exhibía Müller en materia gráfica fuese grabado francés, inglés, holandés o alemán de los siglos XVI al XIX: un conjunto que representaba una apuesta bastante segura en vistas a los coleccionistas porteños de gusto conservador3. En este sentido y con relación a la inserción "comercial" de los grabadores locales, la realización de exposiciones de grabadores argentinos contemporáneos resultó una connotada señal de legitimación, como las muestras del rosarino Gustavo Cochet en 1942 y o la del porteño Mauricio Lasansky en 1943 (imágenes 1 y 2), artistas que conllevaron una significación particular en la trama de la nueva visibilidad del grabado de mediados de siglo en la Argentina.

Si la galería de arte resultaba un espacio "esquivo" o, por lo menos, no tan frecuentado por los grabadores, su circuito de exhibición más habitual se limitaba a los salones oficiales y concursos organizados por distintas agrupaciones, además de la inclusión de sus imágenes en revistas y publicaciones. No se trataba entonces de un problema de delimitación de mercado artístico cuando cíclicamente se explicitaba la concepción del grabado original: a lo sumo, intentaba conformar el mercado más que controlarlo. $\mathrm{O}$, más bien, se apuntaba a prestigiar la disciplina y demarcar su carácter de obra de arte, otorgándole un mejor posicionamiento en el campo al remarcar su "artisticidad" frente a la reproducción fotomecánica.

En este sentido, Víctor Rebuffo planteaba en 1948 que: Frente a la industrialización de los sistemas de reproducción mecánica introducidos por la imprenta moderna, sembrando la confusión y la desorientación en el grabado, y la decadencia de sus valores plásticos, es necesaria una recuperación paulatina de los mismos, reintegrándoles sus principios éticos 4.

La diferencia entre el grabado original y las impresiones por reproducción mecánica5 ya aparecía en la pionera publicación El grabado (imagen 3), cuyos únicos tres números aparecieron en Buenos Aires entre enero y marzo de 1916. La revista, dirigida por Mario A. Canale, se inscribía dentro de las actividades llevadas a cabo por la Sociedad de Grabadores, fundada con el mismo objetivo que la publicación: "hacer conocer el grabado en sus múltiples manifestaciones y difundir su gusto"6. Desde las páginas de la revista, Canale abría un frente estéticocivilizatorio en el que las estampas cumplirían una función primordial en una "campaña regeneradora" al "hacer reaccionar el gusto pervertido por los almanaques de cromo-litografías de vistosos colores que, por lo chillones y 
desarmónicos están en perfecto desacuerdo con la naturaleza"7. La publicación ponía así en evidencia las diferencias entre la reproducción "artísticamente controlada" y la reproducción industrial.

Sin embargo, en un momento fundacional respecto de los parámetros de realización y validación dentro de la disciplina, también desnudaba contradicciones y paradojas: a pesar de la especificación de que "los originales de las obras que reproduce esta revista, numerados, impresos con la firma del autor, pueden adquirirse en la Secretaría de la Sociedad de Grabadores"8 -es decir, algunos aguafuertes- la revista contenía varias estampas xilográficas realizadas a partir del taco original; que éstos no fueran en ese momento considerados como obras “originales" ponía en evidencia que la xilografía no contaba en el campo artístico local de principios del siglo XX con el prestigio necesario como para justificar un control más estricto de su tiraje.

Respecto de las intenciones de la publicación, se mencionaba que la misma sería dedicada a la reacción del gusto artístico en el país, desde la clase social más elevada, hasta el hogar más humilde, tomando como elemento el grabado en todas sus manifestaciones de arte; es decir, que nos proponemos llenar el lugar que nos corresponde en esta naciente democracia argentina9.

El discurso sobre la hipotética función democratizadora del grabado y su posibilidad de devenir en vehículo didáctico-estético venía a continuar el proyecto sostenido por la llamada "generación del ochenta"10; de este modo, la rápida propagación de imágenes que podía llevar a cabo la gráfica debía resultar más que efectiva como "agente civilizatorio".

II

Desde temprano, los discursos sobre el grabado aparecieron enmarcados dentro del tono didáctico, y el tópico de la explicitación a partir del eje de las técnicas de impresión tradicionales -xilografía, litografía, aguafuerte- fue recurrente. El "código de reglamentación del grabado" que, en principio debía actuar de forma implícita, fue enunciado a través de textos que operaban a modo de manual de instrucciones sobre las técnicas y su "infaltable" vinculación con su historia. Apuntando generalmente a un público específico y una circulación restringida a los medios académicos, estos textos sostenían un recorte más o menos similar en torno a la enumeración de artistas y obras; proviniendo de España -como el clásico y muy frecuentado libro de Francisco Esteve Botey-o de Estados Unidos -como el de Arthur M. Hind-proponían un recorrido por nombres de artistas europeos y un marco temporal que llegaba hasta el siglo XIX11.

Sin embargo, el campo del grabado local tenía un creciente historial que hacia los años cuarenta se materializó a través de una serie de revisiones -ediciones y exposiciones- que no solamente funcionaron como estado de la cuestión del grabado sino que operaron como referentes para consagrar un conjunto de nombres y cristalizando una idea de "la gráfica en Argentina" indiscutida hasta la renovación de los años sesenta. Una vasta muestra organizada por Hilarión Hernández Larguía en el Museo Municipal de Bellas Artes Juan B. Castagnino de Rosario (imágenes 4a y 4b), prologada con textos de Alfredo y Alejo González Garaño -coleccionistas y expertos en grabado- proponía en 1942 "un panorama completo de la evolución del arte del grabado en la República Argentina", sosteniendo a la vez "una labor de divulgación, una función didáctica de indudable importancia para el conocimiento de la Historia del Arte Argentino"12. 
Al año siguiente, Oscar Pécora editaba un compendio de la producción xilográfica local que procuraba "una serie con virtualidad estética", donde se remarcaba el protagonismo de la imagen por sobre la textualidad: se trataba de un conjunto de sesenta y cinco grabados en madera editados con el taco original "destinado a los artistas"13. Sin firma ni control estricto de una tirada de gran número de estampas, éstas estaban impresas a partir de las maderas grabadas por los artistas (imágenes $5 a$ y $5 b$ ), un recurso muy utilizado en algunas publicaciones: libros y revistas que incluyeron impresiones con taco original, desde Metrópolis o Plástica de los años treinta a Diagonal Cero u Hoy en la cultura de los sesenta14. La aclaración de que la imagen hubiera sido realizada con esta modalidad otorgaba un viso de mayor prestigio a la publicación y un guiño al lector sobre el valor del material que se le ofrecía: una imagen surgida de la matriz xilográfica -con una mejor definición que la que posibilitaba una impresión fotomecánica a partir de un clisé-, es decir, que no se trataba de una mera reproducción sino de un "original".

De forma paralela a la publicación de Pécora, en ese mismo año 1943 apareció el manual histórico-técnico de Gustavo Cochet (imagen 6) en la recientemente fundada editorial Poseidón, cuyo amplio plan de publicaciones apuntaba a un público general -tal como subraya el título de la colección donde se editó este libro, "Todo para todos"- interesado en cuestiones artísticas15. La inclusión en el plan editorial del libro de Cochet -artista que sería el sexto de los Veintidós pintores de Julio E. Payró, que saldría justo un año después por esta misma editorial16- subrayaba la virtual red de intercambios de una destacada fracción del campo intelectual argentino en su vinculación con los exiliados españoles en el país, y de la cual participaba el editor de Poseidón, Joan Merli. Se pueden repasar algunos datos para dar cuenta de esta trama: Cochet -activo en España entre 1936 y 1939, cuando debe volver a Argentina con el triunfo del franquismo, integrante del connotado Pabellón Español en la Exposición Internacional de París de 193717- y Luis Seoane -artista y editor argentino-gallego exiliado en Argentina en 1936 al estallar la Guerra Civil Española- escribieron para Poseidón; los libros del catalán Merli eran reseñados exhaustivamente en las publicaciones editadas por exiliados gallegos -como Correo Literariodonde también escribían Jorge Romero Brest, José Luis Romero, Córdova Iturburu y Alberto Girri, entre otros; en 1946 se comenzó a publicar Cabalgata, dirigida por Merli con la participación de Seoane y Arturo Cuadrado, entre otras posibles relaciones.

Mientras que el lujoso volumen Veintidós pintores de Julio Payró resumía los distintos lineamientos de la pintura moderna a partir de un conjunto de artistas emblemáticos, consolidando desde su selección un corpus de obras y artistas "faro", Cochet suscribía un texto sobre el grabado que actuaría como discurso de autoridad durante varias generaciones, conformando uno de los puntos de anclaje para el canon local. Por ejemplo, en 1973, durante su retrospectiva en la galería Rubbers, aún se seguía comentando que "muchos conocían a Cochet antes que por su producción pictórica y gráfica [...] por uno de sus libros que años atrás tuvo amplia difusión en el medio artístico local: El grabado, su historia y técnica"18.

La lectura de Cochet apostaba por el valor del métier, sustentándose en una línea tradicional de textos europeos sobre historia y técnica del grabado: Abraham Bosse y Esteve Botey eran, entre otros, los guías que lo conducían para publicar un volumen que, sobrepasando el estrecho círculo de los grabadores, estaba destinado en principio "para el ambiente artístico".

Frente a las "infames tricromías comerciales" -ya denunciadas, recordemos, por Canale, tres décadas atrás-, Cochet sostenía, o más bien auguraba, que "el nuevo resurgimiento que se nota en el grabado no es un suceso 
fortuito. No creo que la pintura pueda volver a su condición pasada de narración anecdótica, de representación en el sentido literario descriptivo; no: la pintura moderna no podrá renunciar a sus conquistas [...].

El grabado, por su formato reducido y porque es esencialmente descriptivo, podría ser el arte que en el futuro tenga más adeptos"19. Introducía de este modo una confrontación: el esquema modernista sostenido por el discurso de gran parte de la pintura contemporánea frente a la función "democrática" del grabado, entendido tanto por sus posibilidades materiales como por la accesibilidad y comprensibilidad del discurso "descriptivo" que, según su lectura, sustentaba su particularidad.

Cochet tenía una mirada conservadora que se manifestaba claramente al referir a las transformaciones que se experimentó en la "técnica moderna en la pintura y el grabado" y al cuestionar la "evolución que experimentaron en su expresión”, preguntándose “¿Nuestra evolución dentro del grabado, puede ser acaso retrogradando? ¿Si no tratamos de superar lo hecho, o por lo menos de mantenerlo en la perfección ya alcanzada, en qué consistirá el adelanto o la evolución?"20 El autor sostenía dos hitos indiscutibles: Durero y Rembrandt, cuyas estampas habían sido expuestas en la galería Müller durante esos años21.

Estas figuras paradigmáticas del grabado occidental, parámetros de perfección técnica y estética, eran referentes clásicos de un grabado consagrado por la historia, los textos y los siglos. ¿Acaso no existía algún otro punto de referencia válido y validado, o es que la mirada ortodoxa de Cochet no le permitía argumentar acerca del "deber ser gráfico" con otros ejemplos más cercanos y eficaces? A través de la selección de estos referentes, Cochet demostraba que su aversión hacia los postulados del modernismo era clara, tan clara como, inversamente, el criterio modernista - con su defensa de la autorreferencialidad y cuestionamiento de la narratividad- ofrecía resistencia hacia el discurso gráfico, mayoritariamente figurativo y de lectura social22.

Sin embargo, estos mismos postulados modernistas interpretados en función de la gráfica ya habían sido enunciados en la Iniciación al grabado de Robert Bonfils, una de las "fuentes de autoridad" de Cochet. Este es el libro que editó Poseidón en 1945, retomando el eje del texto didáctico23. También Bonfils seguía la genealogía canónica del grabado que partía de Durero para concluir con Daumier; sin embargo, aún tratándose de un manual históricotécnico, realizaba una interpretación de la "estética del grabado": mientras sostenía que "en este siglo de viva curiosidad, de instrucción universal, la jerarquía de las obras maestras ha sido puesta a menudo en discusión", introducía elementos novedosos en función de la valorización del grabado: La elección del asunto [en una obra] no nos será indiferente, pero en una época en que la fotografía puede mostrarlo todo, el tema deberá ser solamente accesorio, no documental. Servirá de tema. [...] Una estampa será, pues, gustada por nosotros más por la forma plástica, la escritura y la técnica escogida, la calidad del papel y de la impresión que por lo que representa.

El tema, aun cuando nos interese, no será nunca la causa principal de nuestra estima24.

El tema como recurso accesorio frente a la forma plástica, a la resolución de la imagen: esta reflexión de Bonfils se difundía en los mismos años en que los libros de Julio Payró o Jorge Romero Brest daban cuenta que "la lección modernista había sido estudiada, aprendida y enseñada"25. En el caso de Payró, no sólo sus textos se encuadraban férreamente dentro del recorte del paradigma pictórico -como en Pintura moderna (1942), Veintidós pintores (1944) y Héroes del color (1951) - sino también sus disertaciones y conferencias: por ejemplo, "Pintura de vanguardia, expresión necesaria de nuestro tiempo", dictada en 1949 en el Instituto Popular de 
Conferencias del salón de actos de La Prensa. En ella, Payró aludía a la búsqueda de "un sabio equilibrio entre el concepto del orden y el concepto de la libertad [...] Los mejores pintores contemporáneos se empeñan en aplicar a su arte una fórmula análoga a la de "orden-libertad", creando el orden mediante los recursos formales que dan una sólida estructura al cuadro, y reservándose la libertad en el color"26. Estas alusiones a la libertad en el orden estético contemporáneo, provenientes de un intelectual liberal y antiperonista, cobraban en 1949 una implicación polisémica que excedía el marco del arte27.

III

Las posiciones de Romero Brest sobre el grabado eran por aquellos años más amplias que las de Payró. En su relato tenía un lugar otorgado por la tradición del arte occidental y el peso de la historia, factores determinantes que el crítico no podía permitirse dejar de lado. Paralelamente, a nivel de la coyuntura local, el grabado como "arte social" de fuerte arraigo en la cultura de izquierdas tenía un lugar destacado dentro de las preferencias de la red de intelectuales, editores exiliados (como Merli, Seoane, Lorenzo Varela) y artistas con los que entonces se encontraba vinculado Romero Brest, tanto por sus intervenciones en publicaciones y proyectos editoriales comprometidos con la causa antifascista o con lecturas cercanas a la izquierda -Argentina Libre, La Vanguardia, Correo Literario, Cabalgata- como por la conformación de un núcleo opositor al peronismo, cristalizado en su caso a través de su tibia adhesión al Partido Socialista28.

La idea de "militancia" y de difusión de un imaginario social constituía un punto de anclaje y a la vez de partida para entender el lugar del grabado en el campo local. En los años treinta, al referir al rol del grabado en el marco de los emprendimientos que unían las luchas políticas con la función social del arte, Demetrio Urruchúa proclamaba que: La verdadera misión del grabado, en razón de su posibilidad de fácil circulación y penetración en la mente popular, cuando es una expresión gráfica de la vida del pueblo, debe colocársele entre uno de los medios más eficaces de vinculación y elevación29.

Este era un lineamiento que, retomado desde el enfoque del Romero Brest de los años cuarenta, no podía ser obviado fácilmente o, cuanto menos, no correspondía eludir.

Su posición de compromiso hacia el grabado cristalizó, junto a otras líneas argumentativas, en 1951 con la aparición de su Pintores y grabadores rioplatenses donde, en un doble juego selectivo, construye su propio canon de artistas a partir de una compilación de sus propios escritos y críticas de arte. En este volumen, el crítico no puede (o no se permite) dejar de lado al grabado, opción claramente manifiesta ya desde el propio título del libro.

Así como la inscripción rioplatense funcionaba como estratagema para introducir a Blanes, Figari, Torres-García y Barradas30, también la inclusión de estos grabadores parecía conllevar un rol simbólico, al servir como vía para insertar la producción gráfica en su mapeo de la historia del arte local. El título otorgaba un lugar destacado al grabado, en paridad con la pintura; sin embargo, el apartado específico -"Dibujantes y grabadores rioplatenses"- se resumía en tres figuras: el uruguayo Adolfo Pastor, el argentino Víctor Rebuffo31 (imagen 7) y el exiliado alemán Clément Moreau, los dos últimos con una clara participación en el circuito cultural de izquierda con el que se había vinculado Romero Brest durante los años cuarenta32. 
"El grabado de intención política, de reproducción multiejemplar, es la forma plástica contemporánea de mayor interés, a causa del exacto planteo que suscita a propósito del valor estético y social de una obra de arte" consignaba Romero Brest en el inicio del texto sobre Moreau, una cita diez años anterior a la edición de Pintores y grabadores33. La publicación de esta revisión significaba una bisagra en su carrera -consignaba que "me libera de una carga y me deja en libertad"- y en ella señalaba que sus posicionamientos y preferencias estéticas habían tomado otros rumbos, afianzando su posición en pos de la divulgación del "paradigma modernista" en el que, como hemos señalado, el grabado no encajaba con comodidad.

Por contraposición, Romero Brest publicaba que "en busca del paradigma [del grabado] hay que retornar a la xilografía germánica: ella nos enseña que los temas deben ser accesibles e inteligibles para no exigir esfuerzos intelectuales al espectador y que conviene el empleo de la ingenua alegoría"34: nuevamente, el ejemplo de la gráfica alemana actuaba como el referente de rigor. A la vez, el crítico señalaba que: Resulta extremadamente curioso que la xilografía haya cobrado prestigio precisamente cuando el grabado se independizó como obra de arte [de su función de ilustración literaria] contrariando así la tradición, en el momento que los artistas descubrieron que el material los favorecía en el intento de lograr formas puras y con tendencia a la abstracción35.

Se puede pensar que esta interpretación estaba forzando la situación de la xilografía: por un lado, la "tendencia a la abstracción" aparecía para el autor como un horizonte de expectativas más que como una realidad cercana en la producción de los artistas; por otro lado, en esos años la ilustración literaria permanecía como un polo bien activo dentro de la esfera de producción gráfica.

Si en 1951 el grabado implicaba un discurso que no podía obviar, distinta resultaba su ubicación en 1958 en su Historia de las Artes Plásticas, que con la edición del cuarto volumen completaba la serie aparecida entre 1945 y 194636. Como aclarara el propio Romero Brest, la concreción de ese proyecto editorial "recoge en forma abreviada mis lecciones sobre la materia ante el insistente pedido de mis discípulos"37. Efectivamente, el plan seguía el programa de los cursos de historia del arte que había dictado en la década del cuarenta: en sus clases de esos años, el grabado conformaba un punto de desarrollo en la primera parte del curso "Introducción a la técnica de las artes plásticas", constituyendo un eje que precedía a "la escultura" y antecedía a "las artes derivadas"38.

Este esquema se reacomodó en la edición de Poseidón donde, incluido en el muy tardío último tomo, dejaba manifiesto cuál era el sentido que cobraba en su esquema: desplazado al espacio dedicado a las heterogéneas artes derivadas, junto al mosaico, el vitral, el tapiz, la cerámica, etc., el grabado era el último capítulo de un libro que abordaba estas artes (decorativas, suntuarias, aplicadas, industriales, menores), que tienen, como nota común, la de una estrecha dependencia de sus productos con las necesidades vitales del hombre [...] entendiendo que todas han sido tributarias en su origen y aun en su desarrollo, en mayor o menor escala, de la arquitectura, la escultura y la pintura39.

Es decir, producciones radicalmente alejadas de ese ideal de autonomía estética que sostenía el discurso sustentado por el crítico por aquellos años. La ubicación del capítulo sobre grabado al final del recorrido por las artes derivadas venía a sostener el lugar desplazado, casi marginal o forzado, de una producción que debía ser incluida pero sin saberse del todo bien en dónde incluir. Esta ubicación parecía subrayar que el grabado tenía un lugar híbrido que incomodaba a su mirada modernista, autorreferencial y autónoma. 
Aunque el autor refería en la introducción del tomo que iría a tratar del "grabado de reproducción", el capítulo desarrollaba el frecuentado eje "explicación técnica/historia de la disciplina", recorriendo cronológica y geográficamente distintos hitos del grabado europeo hasta concluir con la figura de Goya, repitiendo un esquema establecido, como se ha señalado, por la bibliografía tradicional. Pero éste no era el único tópico al que recurría Romero Brest: su abordaje se enmarcaba desde la relación entre gráfica e ilustración o gráfica y literatura para destacar las características formales del médium, como así también sus limitaciones en relación con las posibilidades de "creación" u originalidad de otras producciones: ¿No se advierte que el mundo de blanco y negro creado por el grabado está de por sí más de acuerdo con la sobriedad expresiva de la palabra, asentada sobre inconmovibles bases racionales, que con el color inquieto y animal, desobediente e imaginativo? ¿No se advierte que en el planismo obligado de la xilografía y en el nerviosismo de la litografía -las dos técnicas del grabado que son específicamente ilustrativas- se halla el punto de comprensión entre la imagen plástica y la palabra escrita? [...] El carácter reproductivo del grabado hizo que desde temprano se lo empleara para traducir a la madera o el cobre obras realizadas por dibujantes, pintores o escultores, lo que en definitiva determinó la pérdida de su originalidad.

El verdadero arte de grabar, el que produjo las obras más valiosas, es el que cultivaron los grabadores con sentido de creación, los cuales también fueron a veces dibujantes, pintores o escultores, pero sujetos a las posibilidades y limitaciones de los materiales y las técnicas propias del oficio40.

El texto de Romero Brest presentaba un recorrido anclado en el referente goyesco como último punto; este no es el único dato para interpretar esta obra como un escrito "viejo", sino también por la bibliografía citada, desactualizada ya para ese momento, o por el hecho de que no hiciera referencia a la obra gráfica argentina que comenzaba a cobrar una nueva presencia en el circuito local pero que no estaba incluida en los libros sobre grabado occidental de ese momento. Todos estos factores hacen considerar a este texto como correcto resumen de los libros "clásicos" sobre el tema, incluyendo al manual de Cochet como nota novedosa41. Romero Brest no había elaborado un discurso propio sobre grabado "universal", sino que tomaba la bibliografía clásica y seguía sus lineamientos; desconocía así referencias más actualizadas, como el texto del grabador inglés Stanley William Hayter (imagen 8), a quién el crítico conocía bien y que, si bien dentro de círculos restringidos, circulaba en Buenos Aires desde principios de los años cincuenta42. Esta exclusión se debía, sin dudas, a que el de Romero Brest era un texto escrito hacía ya varios años.

La gráfica tomaba entonces nuevos rumbos que no eran registrados en esta summa. Precisamente en ese mismo 1958 ya circulaban en Argentina los grabados "modernistas" que tan bien podían enmarcarse dentro de las directivas de su lectura (imagen 9). La abstracción -antes vedada en forma implícita de acuerdo al canon del grabado local- comenzaba a ser tomada en cuenta como parte del espectro de posibilidades para los artistas argentinos, y a ser enviada y admitida en salones y envíos oficiales al exterior.

Una lectura más personal y problematizadora sostendría Romero Brest en 1963 cuando, a instancias de una serie de grabados de Mabel Rubli, escribía que: Se contempla un grabado en dos planos de existencia, sin que se confundan del todo: el de la imagen única que se tiene ante los ojos y el de las imágenes múltiples que se saben han sido hechas.

Acaso el contemplador no advierta tal duplicidad, mas, ¿puede ignorarla el grabador? ¿No sabe que el acto original, la plancha, pierde intensidad al extenderse en cada copia? Por eso el grabado ha sido y es popular, a 
causa de su multiejemplaridad, admitiendo el tono narrativo que rechaza la pintura y la intención didáctica que apenas tolera. [...] Quienquiera, pues, comprender estos grabados, no los mire como si fuesen cuadros; mantenga las formas de todos in mente y rehaga la narración que contienen43.

Puntos de conflicto entre la unicidad, la multiplicidad y la editabilidad, lo popular, lo didáctico, lo narrativo y el acto creativo original: con esta lectura, Romero Brest remarcaba un lugar problemático del grabado en el relato del arte moderno.

Notas

1. En este trabajo amplío algunas lecturas presentadas en mi libro (2012). Arte plural. El grabado entre la tradición y la experimentación 1955-1973, Buenos Aires: Edhasa.

2. Caillet-Bois, H. (1944, 8 de julio). "Prefacio”, Exposición del grabado universal. Santa Fe: Museo Rosa Galisteo de Rodríguez, p. 10.

3. Recordemos también que Müller era el galerista de Fernando Fader. La galería de este alemán naturalizado fue fundada en 1913, se trasladó a la calle Florida en 1927 y se instaló en su local definitivo en 1934; entre sus ocho salas se encontraba el Gabinete de Estampas. Cerró a fines de 1955. Algunos rasgos sobre esta galería en Eduardo Eiriz Maglione, “Las galerías de arte bonaerenses”, Lyra, año XVI, n. 171-173, segundo número extraordinario de $1958, \mathrm{~s} / \mathrm{p}$.

4. Rebuffo, V. (1948). “El grabado". Ars, a. VII, n. 37, s/p. Buenos Aires.

5. Sobre esta cuestión, cf. Dolinko, S. "Grabados originales multiplicados en libros y revistas", en Laura Malosetti Costa y Marcela Gené (comps.) (2009). Impresiones porteñas. Imagen y palabra en la historia cultural de Buenos Aires, Buenos Aires: Edhasa, pp. 165-194.

6. El grabado, Buenos Aires, n. 1, enero de 1916, s/p. Sobre esta publicación, cf. Dolinko, S. (2003). "Arte para todos". El grabado como estrategia para la popularización del arte, Buenos Aires, FIAAR; Baldasarre, M. I. "La vida artística de Mario A. Canale" en Amigo, R. y Baldasarre, M. I. (eds.) (2006). Maestros y discípulos. El arte argentino desde el archivo Mario A. Canale, Buenos Aires, Fundación Espigas; Dolinko, S. (2013). "Cooperativa gráfica: un recorrido por algunos colectivos de la Argentina" en Estampa 11, n. 3-4, Universidad Nacional de Cuyo, pp. 44-63.

7. Anónimo, "Exposiciones de grabados", El grabado, (1916, enero) n. 1, p. 4. Una lectura sobre el proceso de industrialización de la imagen en este período en el texto de Sandra Szir (2005) "Los orígenes de la cultura visual masiva en Buenos Aires y sus condiciones materiales de posibilidad", en Original-copia... original?, Buenos Aires: CAIA, pp. 219-230.

8. El grabado, (1916, marzo), n. 3, p. 12.

9. Anónimo (1916, enero), s/t, [Revista] El grabado, n. 1, p. 1. 
10. Laura Malosetti Costa ha señalado que este proyecto sostenía la pretensión que sus artistas incidieran en “'educar el buen gusto', 'inculcar ideales', 'enseñar verdades que dicta el espíritu', erradicar no sólo la ignorancia y el 'mal gusto' de las masas 'inertes' y de los nuevos burgueses materialistas sino también los hábitos violentos de un pasado 'bárbaro'”. Malosetti Costa, L. (2001). Los primeros modernos. Arte y sociedad en Buenos Aires a fines del siglo XIX. Buenos Aires: Fondo de Cultura Económica, p. 55.

11. Esteve Botey, F. (1935). Historia del grabado. Barcelona: Labor; Hind, A. M. (1923). A history of engraving \& etching from the 15th century to the year 1914. Boston-New York: Houghton Mifflin Company. A pesar que el texto de Hind prometía una revisión del grabado de principios del siglo XX, éste se acotaba a unos escasos párrafos.

12. El grabado en la Argentina, 1705-1942, Rosario, Museo Municipal de Bellas Artes "Juan B. Castagnino", 1942. Sobre esta exposición, cf. Dolinko, S. (2011). "Museo imaginario, Museo Castagnino: el grabado como arte autónomo (Rosario, 1942)", en La autonomía del arte: debates en la teoría y en la praxis, Buenos Aires, CAIA, pp. 325-336; Florio, S. y Rippa, L. (2013). “El grabado en la Argentina: un aporte para 'el conocimiento' de la historia del arte nacional", en María José Herrera (ed.), Exposiciones de arte argentino y latinoamericano. El rol de los museos y los espacios culturales en la interpretación y la difusión del arte, Buenos Aires, Fundación Alfonso y Luz Castillo, pp. 47-61.

13. Pécora, O. y Barranco, U. (eds.) (1943). Sesenta y cinco grabados en madera. La xilografía en el Río de la Plata, Buenos Aires, Ediciones Plástica. La circulación del material excedió al círculo de artistas: por ejemplo, fue exhibido en la sede de la Unión Panamericana de Washington en marzo de 1945. Cf. Anuario Plástica 1945, Buenos Aires, p. 186.

14. Diagonal Cero, publicada por Edgardo-Antonio Vigo en La Plata entre 1962 y 1968, incluyó numerosas estampas suyas y de otros artistas latinoamericanos, editadas en sus páginas o como cuadernillos anexos; Hoy en la cultura publicó, por ejemplo, una xilografía de Antonio Berni "impresa con taco original" (n. 22, agosto de 1965).

15. Cochet, G. (1943). El grabado. Historia y técnica, Buenos Aires: Poseidón. La editorial había sido fundada el año anterior; sobre Poseidón, cf. María Amalia García, "El señor de las imágenes. Joan Merli y las publicaciones de artes plásticas en la Argentina en los '40", en Patricia Artundo (dir.), Artes en revista. Publicaciones culturales en la Argentina. 1900-1950, Rosario, Beatriz Viterbo, 2008.

16. Payró, J. E. (1944). Veintidós pintores, facetas del arte argentino, Buenos Aires, Poseidón. Sobre esta relación, cf. la carta de Julio E. Payró a Gustavo Cochet (Buenos Aires, 13 de julio de 1944, Archivo Cochet, Fundación Espigas) donde le solicita que le facilite material para las reproducciones a incluir en este volumen.

17. Expone el aguafuerte Vista del canal, según consta en el catálogo Pabellón Español 1937. Exposición Internacional de París, Madrid, Museo Nacional Centro de Arte Reina Sofía, 1987, p. 197. Cochet fue el único artista argentino incluido en este pabellón y junto a Alexander Calder, uno de los pocos extranjeros.

18. Monzón, H. (1973). “Interesante retrospectiva de un maestro rosarino”, La Opinión, 10 de mayo de 1973, p. 19. 
19. Cochet, G. El grabado... op. cit., p. 107.

20. Ibid., p. 146.

21. También en Müller, como ya ha señalado, el propio Cochet también había tenido su exposición individual en 1942.

22. Sobre los discursos modernistas en la plástica, cf. Frascina, F. (ed.) (1985). Pollock and After. The Critical Debate. Nueva York: Harper \& Row; Danto, A. C. (1999). Después del fin del arte. El arte contemporáneo y el linde de la historia, Barcelona: Paidós; Wood, P.; Frascina, F.; Harris, J. y Harrison, Ch. (1999). La modernidad a debate. El arte desde los cuarenta. Madrid: Akal, entre otros. Un abordaje sobre las tensiones entre modernismo pictórico y gráfica social en mi libro Arte plural... op. cit., pp. 24-31.

23. Bonfils, R. (1945). Iniciación al grabado. Buenos Aires: Poseidón. [Ed. original, Initiation à la gravure, R. Ducher, Paris, s/f.] Traducción de Roger Pla.

24. Ibid., p. 12.

25. Giunta, A. (2001). Vanguardia, internacionalismo y política. Arte argentino en los sesenta. Buenos Aires: Paidós, p. 220.

26. "Hablóse de pintura de vanguardia en el Instituto Popular de Conferencias". La Prensa, 1 de octubre de 1949, p. 6.

27. Estos recursos retóricos también eran empleados por Romero Brest como estrategia para aludir a su interpretación sobre el clima cultural de aquellos años del peronismo. En su crítica al Salón Nacional de 1948 empleaba las nociones de "moral", "reacción" y "libertad" para aludir sutilmente a su visión sobre la situación política del momento. Cf. "Crítica. XXXVIII Salón Nacional de Artes Plásticas”, Ver y Estimar (1948). Vol. II, n. 6, septiembre de 1948, p. 63.

28. Cf. "A Damián Carlos Bayón, discípulo y amigo", mimeo, Archivo Jorge Romero Brest, Facultad de Filosofía y Letras, Universidad de Buenos Aires, c6-s6-A. Reproducido en Romero Brest, J. (2004). Escritos I (1928-1939). Buenos Aires: Instituto de Teoría e Historia del Arte “Julio E. Payró”, FFyL-UBA, pp. 45-46.

29. D.U.C. [Demetrio Urruchúa] (1933). "Artes Plásticas”, Nervio. Crítica. Artes. Letras, Buenos Aires, a. 3, n. 30, diciembre de 1933, p. 46.

30. Cf. Malosetti Costa, L. "Romero Brest y la historiografía del arte argentino”, en Giunta, A. y Malosetti Costa, L. (comp.) (2005). Arte de posguerra. Jorge Romero Brest y la revista Ver y Estimar. Buenos Aires: Paidós, p. 285.

31. Aunque Rebuffo nació en Turín, Italia, en 1903, al año siguiente se radicó en el país junto a su familia. En 1947 adoptó la ciudadanía argentina. Sobre este artista, cf. Gené, M. y Dolinko, S. (2008). Rebuffo y el grabado moderno. Buenos Aires: Fundación Mundo Nuevo. 
32. El dibujante y grabador alemán, exiliado en Argentina desde 1935, tuvo una intensa participación en el campo local, sobre todo desde sus trabajos en publicaciones combativas y antifascistas como Izquierda. Crítica y Acción socialista, Unidad. Por la defensa de la cultura (órgano de la AIAPE, Agrupación de Intelectuales, Artistas, Periodistas y Escritores), Argentinisches Tageblatt, La Vanguardia o Argentina Libre donde, durante los primeros años, tuvo un espacio permanente como ilustrador. Véase Moreau, C. (1994). Con el lápiz contra el fascismo. Buenos Aires: Goethe-Institut y Fundación Banco Patricios.

33. Romero Brest, J. (1951). "Clément Moreau, dibujante político", Pintores y grabadores rioplatenses, Buenos Aires, Argos, p. 261. Publicado originalmente en Argentina Libre, enero 27 y 30, febrero 6 de 1941. Sobre la actuación de Romero Brest en esta publicación, cf. Plante, I. (2003 ). “'El fuego universal de la libertad' que avivó las críticas de Jorge Romero Brest en la revista antifascista Argentina Libre (1940-1943)" en IX Jornadas Interescuelas/ Departamentos de Historia, Universidad Nacional de Córdoba, CD-ROM.

34. Romero Brest, J. "Víctor Rebuffo y el destino de la xilografía en Argentina", Pintores y grabadores rioplatenses, op. cit., p. 230.

35. Ibid., p. 233.

36. Romero Brest, J. Historia de las artes plásticas. Tomo I: Introducción a la historia de las artes plásticas, (1945) Tomo II: La pintura (1945), Tomo III: La arquitectura y la escultura (1946), Tomo IV: Las Artes derivadas (1958). Buenos Aires: Editorial Poseidón.

37. Romero Brest, J. (1945). Historia de las Artes Plásticas. Tomo I, Introducción a la Historia de las Artes Plásticas. Buenos Aires: Poseidón, p. 9.

38. Cf. por ejemplo el programa de los "Cursos de estética e historia de las artes plásticas", Librería Fray Mocho, abril-noviembre 1947 y abril-setiembre 1948. Archivo JRB, c 18-53-f y g.

39. Romero Brest, J. Historia de las artes plásticas. Las Artes derivadas, op. cit., p. 7. Contrariamente, en el primer tomo de la serie le otorgaba al grabado un registro "autónomo", considerando que las "artes decorativas, suntuarias, aplicadas, industriales o menores, tienen una estrecha relación con las artes plásticas puras: la arquitectura, la pintura, la escultura y el grabado". Historia de las artes plásticas, tomo I, p. 121.

40. Romero Brest, J. Historia de las artes plásticas. Las Artes derivadas, op. cit., p. 391. El destacado es mío.

41. Por su parte, al propio autor le pareció "muy bueno" comparado con los otros tres tomos, tal como lo menciona en “A Damián Carlos Bayón, discípulo y amigo”, op. cit., p. 49.

42. Hayter, S. W. (1949). New Ways of Gravure. Londres: Routledge \& Kegan Paul limited. En 1956, Romero Brest presentó una exposición del artista inglés en el Museo Nacional de Bellas Artes, entonces bajo su dirección.

43. Romero Brest, J. (1963). s/t, prólogo a la exposición de Mabel Rubli en la Galería Nice, auspiciada por el Museo de Arte Moderno de Buenos Aires, setiembre de 1963. El subrayado es del original. 
Bibliografía

A.A.V.V.: [Catálogo] (1987). Pabellón Español 1937. Exposición Internacional de París. Madrid: Museo Nacional Centro de Arte Reina Sofía.

A.A.V.V.: [Revista] (1965, agosto). Hoy en la cultura. Buenos Aires.

Baldasarre, M. I. (2006). "La vida artística de Mario A. Canale” en Amigo, R. y Baldasarre, M. I. (ed.), Maestros y discípulos. El arte argentino desde el archivo Mario A. Canale. Buenos Aires: Fundación Espigas.

Bonfils, R. (1945) Iniciación al grabado. Buenos Aires: Poseidón.

Caillet-Bois, H. (1944). Exposición del grabado universal, en Prefacio, Santa Fe: Museo Rosa Galisteo de Rodríguez.

Canale, M. A. (Dir). (1916, enero - marzo). [Revista] El grabado, n 1- 3. Buenos Aires: Sociedad de Grabadores.

Cochet, G. (1943). El grabado. Historia y técnica. Buenos Aires: Poseidón.

Danto, A. C. (1999) Después del fin del arte. El arte contemporáneo y el linde de la historia. Barcelona: Paidós.

Dolinko, S. (2003). "Arte para todos". El grabado como estrategia para la popularización del arte. Buenos Aires: FIAAR.

Dolinko, S. (2012). Arte plural. El grabado entre la tradición y la experimentación 1955-1973. Buenos Aires: Edhasa.

Dolinko, S. (2013). "Cooperativa gráfica: un recorrido por algunos colectivos de la Argentina" en Estampa 11, n. 3-4. Universidad Nacional de Cuyo.

Dolinko, S. (2009). "Grabados originales multiplicados en libros y revistas”, en Malosetti Costa, L. y Gené, M. (comps.). Impresiones porteñas. Imagen y palabra en la historia cultural de Buenos Aires. Buenos Aires: Edhasa.

Dolinko, S. (2011). "Museo imaginario, Museo Castagnino: el grabado como arte autónomo (Rosario, 1942)", en La autonomía del arte: debates en la teoría y en la praxis. Buenos Aires: CAIA, 2011.

D.U.C. [Demetrio Urruchúa]. (1933 diciembre). Artes Plásticas. Nervio. Crítica. Artes. Letras. Buenos Aires, a. 3, n. 30 , p. 46.

Eiriz Maglione, E. (1958). Las galerías de arte bonaerenses, en Lyra, año XVI, n. 171-173, segundo número extraordinario.

Esteve Botey, F. (1935). Historia del grabado. Barcelona: Labor.

Florio, S. y Rippa, L. (2013). “El grabado en la Argentina: un aporte para 'el conocimiento' de la historia del arte nacional”, en Herrera, M. J. (ed.), Exposiciones de arte argentino y latinoamericano. El rol de los museos y los 
espacios culturales en la interpretación y la difusión del arte, Buenos Aires: Fundación Alfonso y Luz Castillo.

Frascina, F. (ed.). (1985). Pollock and After. The Critical Debate. Nueva York: Harper \& Row.

García, M. A. (2008). “El señor de las imágenes. Joan Merli y las publicaciones de artes plásticas en la Argentina en los '40", en Artundo, P. (dir.), Artes en revista. Publicaciones culturales en la Argentina. 1900-1950, Rosario: Beatriz Viterbo.

Gené, M. y Dolinko, S. (2008). Rebuffo y el grabado moderno. Buenos Aires: Fundación Mundo Nuevo.

González Garaño, Alfredo y Alejo (1942). [Prólogo de la exposición]. El grabado en la Argentina, 1705-1942, Rosario: Museo Municipal de Bellas Artes "Juan B. Castagnino".

Giunta, A. (2001). Vanguardia, internacionalismo y política. Arte argentino en los sesenta. Buenos Aires: Paidós.

Hayter, S. W. (1949). New Ways of Gravure. Londres: Routledge \& Kegan Paul limited.

Hind, A. M. (1923). A history of engraving \& etching from the 15th century to the year 1914, Boston-New York: Houghton Mifflin Company.

Malosetti Costa, L. (2001). Los primeros modernos. Arte y sociedad en Buenos Aires a fines del siglo XIX. Buenos Aires: Fondo de Cultura Económica.

Malosetti Costa, L. (2005). Romero Brest y la historiografía del arte argentino, en Giunta, A. y Malosetti Costa, L. (comp.) (2005). Arte de posguerra. Jorge Romero Brest y la revista Ver y Estimar. Buenos Aires: Paidós.

Monzón, H. (1973. 10 de mayo): Interesante retrospectiva de un maestro rosarino. La Opinión, p. 19.

Moreau, C. (1994). Con el lápiz contra el fascismo. Buenos Aires: Goethe-Institut y Fundación Banco Patricios.

Payró, J. E. (1949. 1 de octubre). Hablóse de pintura de vanguardia en el Instituto Popular de Conferencias. La Prensa, p. 6.

Payró, J. E. (1944). Veintidós pintores, facetas del arte argentino. Buenos Aires: Poseidón.

Pécora, O. y Barranco, U. (editores.). (1943). Sesenta y cinco grabados en madera. La xilografía en el Río de la Plata. Buenos Aires: Ediciones Plástica.

Plante, I. (2003). “'El fuego universal de la libertad' que avivó las críticas de Jorge Romero Brest en la revista antifascista Argentina Libre (1940-1943)" en IX Jornadas Interescuelas/ Departamentos de Historia, Universidad Nacional de Córdoba, CD-ROM.

Romero Brest, J. [Mimeo]. "A Damián Carlos Bayón, discípulo y amigo”. Archivo Jorge Romero Brest, Facultad de Filosofía y Letras, Universidad de Buenos Aires, c6-s6-A. Reproducido en Romero Brest, J. (2004). Escritos I (1928-1939), Buenos Aires: Instituto de Teoría e Historia del Arte “Julio E. Payró”. FFyL-UBA. 
Romero Brest, J. (1951). "Clément Moreau, dibujante político", Pintores y grabadores rioplatenses, Buenos Aires: Argos. Publicado originalmente en Argentina Libre, enero 27 y 30, febrero 6 de 1941.

Romero Brest, J. (1948, septiembre) Crítica. XXXVIII Salón Nacional de Artes Plásticas. En Ver y Estimar, vol. II, n. 6. Romero Brest, J. Historia de las artes plásticas. Tomo I: Introducción a la Historia de las Artes Plásticas, (1945) Tomo II: La pintura (1945), Tomo III: La arquitectura y la escultura (1946), Tomo IV: Las Artes derivadas (1958). Buenos Aires: Editorial Poseidón.

Romero Brest, J. (1963, septiembre). Prólogo [S/t] a la exposición de Mabel Rubli en la Galería Nice, auspiciada por el Museo de Arte Moderno de Buenos Aires.

Romero Brest, J. (1947, abril - noviembre y 1948, abril - septiembre). [Programa de los] "Cursos de estética e historia de las artes plásticas", Librería Fray Mocho. En: Archivo JRB, c 18-53-f y g.

Romero Brest, J. (1951). Víctor Rebuffo y el destino de la xilografía en Argentina. Pintores y grabadores rioplatenses. Buenos Aires: Argos.

Rebuffo, V. (1948). El grabado. Ars, a. VII, n. 37. Buenos Aires.

Szir, S. (2005). "Los orígenes de la cultura visual masiva en Buenos Aires y sus condiciones materiales de posibilidad", en Original-copia... original?. Buenos Aires: CAIA.

Vigo, E. A. (Dir.). (1962-1968). [Revista] Diagonal Cero. La Plata.

Wood, P., Frascina, F., Harris, J. y Harrison, Ch. (1999). La modernidad a debate. El arte desde los cuarenta. Madrid: Akal.

Abstract:

The article takes a tour on some texts related to the role and significance of the engraving that circulated in the argentine cultural field in the mid-twentieth century, considering the proposals of authors like Gustavo Cochet and Jorge Romero Brest who in this time were making selections of some texts that over time would become canonical for art history.

Key Words:

engraving - canon - historiography - 20th. Century - Cochet - Romero Brest.

Resumo:

O artigo apresenta um percurso por algumas leituras sobre o rol e significação da gravação que circularam por o campo cultural argentino em meados do século XX, considerando as abordagens de autores como Gustavo Cochet e Jorge Romero Brest quem selecionava e sustentava leituras que com o tempo se tornariam canônicas para a história da arte.

Palavras chave: 
gravação - cânon - historiografia - século XX - Cochet - Romero Brest.

Lecturas sobre el grabado en la Argentina a mediados del siglo XX1 fue publicado de la página 31 a página48 en Cuadernos del Centro de Estudios de Diseño y Comunicación № 60 